\title{
HAFIDZ CILIK: POLA ASUH DAN MODEL PENDIDIKAN DINI HAFIDZ CILIK DI KELURAHAN KARAMPUANG KECAMATAN PANAKKUKANG KOTA MAKASSAR
}

\author{
Andi Pawellangi ${ }^{1}$ Ashari Ismail $^{2}$ \\ ${ }^{1}$ Mahasiswa Program Studi Sosiologi Fakultas Ilmu Sosial \\ Universitas Negeri Makassar \\ email : andipawel02@gmail.com \\ ${ }^{2}$ Dosen Sosiologi/ Universitas Negeri Makkassar \\ Email:ashari.ismail@unm.ac.id
}

\begin{abstract}
ABSTRAK
Penelitian ini bertujuan untuk mengetahui: 1) Pola Asuh Hafidz Cilik, 2) Model Pendidikan Dini Hafidz Cilik yang dapat menumbuhkan Hard Skill dan Soft Skill bagi Hafidz Cilik. Hasil penelitian menunjukkan bahwa: a) Pola Asuh Hafidz Cilik: 1) interaksi antar anggota keluarga, 2) pengenalan nilai positif dan negatif, 3) bentuk berpikir (mind set), 4) internalisasi nilai-nilai, 5) tingkah laku, 6) kaidah-kaidah (kepercayaan, kesusilaan, kesopanan, dan hukum). b) Model Pendidikan Dini Hafidz Cilik yang dapat menumbuhkan hard skill dan soft skill bagi hafidz cilik ialah Metode Keteladanan (Uswah), hard skill berupa kemampuan membaca dan menghafalkan Al Quran. Soft skill berupa kemampuan berkomunkasi, berperilaku baik, disiplin dan mempunyai daya ingat yang kuat.
\end{abstract}

Kata Kunci : Pola asuh, Hafidz cilik, Model pendidikan dini.

\begin{abstract}
This study aims to determine: 1) Childhood Hafidz Parenting Patterns, 2) Early Hafidz Early Education Models that can grow Hard Skills and Soft Skills for Young Hafidz. The results showed that: a) Childhood Hafidz parenting: 1) interaction between family members, 2) introduction of positive and negative values, 3) form of thinking (mind set), 4) internalization of values, 5) behavior, 6) rules (trust, decency, courtesy, and law). b) Early Hafidz Early Education Model that can grow hard skills and soft skills for young hafidz is the Exemplary Method (Uswah), hard skills in the form of the ability to read and memorize the Qur'an. Soft skills such as the ability to communicate, behave well, be disciplined and have a strong memory.
\end{abstract}

Keywords : Parenting, Little Hafidz, Early education model.

\section{PENDAHULUAN}

Keluarga dan pendidikan adalah dua sisi yang saling berkaitan. Keluarga adalah kelompok sosial yang paling kecil yang terdiri dari ayah, ibu dan anak. Keluarga merupakan salah satu pusat pendidikan. Keluarga memiliki kekhasannya sendiri yang berbeda dengan lembaga pendidikan yang 
lain. Di keluarga, pendidikan bukan berjalan atas dasar ketentuan yang memang diformalkan, akan tetapi tumbuh dari kesadaran moral sejati antar orangtua dan anak. Anak adalah manusia yang masih kecil dan berasal dari sesuatu atau dilahirkan. Keluarga, sekolah dan masyarakat disebut tri pusat pendidikan, namun keluarga yang memberikan pengaruh perama kali terhadap anak.

Keluarga merupakan pusat pendidikan yang paling penting karena keluarga adalah lembaga yang paling berpengaruh dibandingkan lembaga yang lain. Beberapa tahun terakhir, masyarakat dihebohkan dengan fenomena kemunculan hafidzh cilik tingkat nasional bahkan menjadi suatu kompetisi dalam media pertelevisian, dimana anak-anak ini masih berusia 3 tahun sampai 7 tahun baik laki-laki maupun perempuan untuk unjuk gigi atas "keajaibannya" dalam menghafalkan ayat-ayat suci Al-Qurean. Ada yang hafal 1-5 juz saja, adapula yang sudah hafal 30 juz dengan lancar meskipun belum tentu anak tersebut sudah bisa membca kalam Allah.

Tentu orang tua manapun yang melahirkan dan membesarkan anak dengan "keajaiban" tersebut akan merasa bangga dan sangat bersyukur. Tidak pula masyarakat umum pastinya akan takjub dan berharap memiliki anak yang demikian, mengingat banyak sekali kemulian yang diberikan Allah. bagi para penghafal Al-Qur"an. Salah satunya ialah menjadi syafa"at (penolong) bagi 10 anggota keluarganya, dan orang tua dari penghafal Al-Qurean tersebut akan dipakaikan jubah kemuliaan ketika di Surga kelak. Tentu, ini dapat terwujud melalui proses yang panjang serta peranan orang tua yang mempunyai andil dalam menorehkan tinta bagi kehidupan mereka melalui pola asuh.

Dalam proses tumbuh kembang seorang anak, terdapat beberapa tempat bertumbuhnya kecerdasan jamak Multiple Intelligence. Kecerdasan ini akan berkembang dengan adanya hubunganhubungan dengan pihak luar (terutama keluarga \& orang tua) yang dibangun secara ikhlas, intensif, dan efisien. Salah satu bagian dari kecerdasan jamak adalah kecerdasan Spiritual, yang diyakini sebagai kecerdasan yang paling esensial dalam kehidupan manusia Maka hal yang perlu diperhatikan pertama kali adalah kesiapan orang tua dalam mendidik anak-anaknya.

Berdasarkan penjelasan yang telah dipaparkan diatas, terdapat suatu masalah yaitu bagaimana bisa anak kecil dalam keluarga sudah mampu menghafalkan Al-Qur" an sejak dini, sementara mereka secara normalnya belum bisa melakukan hal seberat itu. Mengingat pola pikir anak yang masih bersifat konkret, hal semacam kemuliaan menghafal Al-Quran, syafa"at-syafa"at, dan hal-hal lainnya akan sulit dicerna oleh anak. Tujuan dari penelitian ini ialah Mengidentifikasi dan mendeskripsikan pola asuh dan model pendidikan dini Hafidz Cilik di Kelurahan Karampuang, Kecamatan Panakukang, Kota Makassar.

\section{METODE}

Jenis penelitian ini adalah penelitian kualitatif dengan penekanan Observasional Analitik melaui pendekatan Cross Sectional. Yaitu dengan observasi langsung ke objek sasaran riset Penelitian ini akan dilaksanakan di Kelurahan Karampuang, Kecamatan Panakukang, Kota Makassar. Data primer diperoleh dari informan, penentuan informannya dilakukan dengan cara purposive sampling dengan persyaratan yaitu orang tua yang memiliki anak hafidz cilik. Pengumpulan data primer menggunakan wawancara mendalam dan observasi. Pengumpulan data sekunder diperoleh dari dokumentasi. Aktivitas dalam analisis data yaitu data reduction, data display dan conclusion drawing/verification.

\section{HASIL DAN PEMBAHASAN}

Kata pola asuh berasal dari dua kata yaitu pola dan asuh. Pola dapat diartikan sebagai corak tenun, corak batik, potongan kertas yang dipakai mal untuk memotong bakal baju. Sedangkan asuh berarti memelihara dan mendidik anak kecil. Secara umum pola asuh dapat diartikan sebagai corak atau model memelihara dan mendidik anak. Yang dimaksud pola asuh dalam penelitian ini yaitu sistem, cara atau pola yang digunakan atau diterapkan dalam kehidupan sehari-hari terhadap anak. Sistem atau cara tersebut meliputi cara mengasuh, membina, mengarahkan, membimbing dan memimpin anak. Pola ini tentu saja dalam setiap keluarga mempunyai pola yang berbeda antara satu keluarga dengan keluarga yang lainnya.

Bentuk pola asuh secara garis besar menurut Baumrind yang dikutip oleh Kartini Kartono terdapat 3 macam pola asuh orang tua, yaitu: 


\section{1) Pola Asuh Otoriter (Authorotatian)}

Dalam kamus bahasa Indonesia otoriter berarti berkuasa sendiri dan sewenang-wenang. Menurut Singgih D Gunarsa dan Ny. Y. Singgih D Gunarsa, pola asuh otoriter adalah suatu bentuk pola asuh yang menuntut anak agar patuh dan tunduk terhadap semua perintah dan aturan yang dibuat oleh pengasuh tanpa ada kebebasan untuk bertanya atau mengemukakan pendapatnya sendiri.

Pola asuh ini cenderung menentukan standart yang mutlak harus dituruti. Biasanya dibarengi dengan ancaman-ancaman. Pengasuh tipe ini cenderung memaksa, memerintah, menghukum. Apabila anak tidak mau melakukan apa yang dikatakan oleh pengasuh, maka pengasuh itu tidak segan-segan untuk menghukum anak. Pengasuh sperti ini juga tidak mengenal kompromi dan berkomunikasi dalam satu arah. Adapun ciri-ciri pola asuh otoriter adalah sebagai berikut:

a) Anak harus mematuhi aturan pengasuh dan tidak boleh membantahnya.

b) Pengasuh cenderung menceri kesalahan-kesalahan anak dan kemudian menghukumnya.

c) Pengasuh cenderung memberi perintah dan larangan kepada anak.

d) Jika terdapat perbedaan pendapat antara pengasuh dengan anak, maka anak dianggap pembangkang.

e) Pengasuh cenderung memaksakan disiplin.

2) Pola Asuh Permisif

Pengasuhan permisif adalah pengasuhan yang memberikan kebebasan penuh kepada anak untuk memilih dan mengatur perilakunya. Pola pengasuhan ini berbalikkan dengan pengasuhan otoriter. Pola ini memberikan pengawasan yang sangat longgar. Memberikan kesempatan pada anak asuh untuk melakukan sesuatu tanpa pengawasan yang cukup darinya. Mereka cenderung tidak menegur atau memperingatkan apabila anak sedang dalam masalah atau bahaya. Adapun yang termasuk pola asuh permisif adalah sebagai berikut:

a) Membiarkan anak bertindak sendiri tanpa memonitor dan membingbingnya.

b) Mendidik anak asuhnya secara acuh tak acuh, bersikap pasif dan masa bodoh.

c) Mengutamakan kebutuhan material saja.

d) Membiarkan saja apa yang dilakukan anak (terlalu memberikan kebebasan untuk mengatur dirinya sendiri tanpa ada peraturan-peraturan dan norma-norma yang digariskan oleh pengasuhnya).

e) Kurang sekali keakraban dan hubungan yang hangat dalam dalam keluarga.

3) Pola Asuh Demokrasi

Pola asuh demokrasi adalah pola asuh yang memprioritaskan kepentingan anak, tetapi tidak ragu-ragu dalam mengendalikan mereka. Para pengasuh seperti ini bersikap rasional, selalu mendasari tindakannya pada rasio-rasio dalam berpikir. Pengasuh tipe ini juga bersifat realistis terhadap kemanpuan anak, tidak berharap yang berlebihan yang melampau kemanpuan anak. Pengasuh tipe seperti juga memberikan kebebasan pada anak untuk memilih dan juga memberikan sesuatu tindakan dan pendekatan kepada anak besifat hangat. Mereka melihat bahwa anak berhak mengetahui mengapa peraturan ini dibuat, dan mereka diberikan kesempatan untuk mengemukakan pendapat sendiri bila mereka menganggap peraturan tersebut tidak adil, sekalipun anak masih kecil, mereka diberi kejelasan mengenai peraturan tersebut. Adapun ciri-ciri pola asuh demokratis adalah sebagai berikut:

a) Menentukan peraturan dan disiplin dengan memperhatikan dan mempertimbangkan alasan-alasan yang dapat diterima dan dipahami dan dimengerti oleh anak.

b) Memberikan pengarahan tentang perbuatan yang harus dipertahankan oleh anak dan yang tidak baik agar ditinggalkan.

c) Memberikan bimbingan dengan penuh pengertian.

d) Dapat menciptakan suasana komunikatif antara pengasuh, anak dan sesama keluarga.

Ada beberapa model pendidikan dini, yaitu sebagai berikut ;

\section{Modelling}

Indivudu mempelajari berbagai bentuk perilaku dengan jalan mengamati perilaku-perilaku yang nampak ditunjukkan oleh individu lain sebagai model Teori ini dikenal dengan teori modelling. Bandura berasumsi bahwa seseorang dapat mempelajari sesuatu dengan memperhatikan perilaku orang lain dan akan menjadi representasi kognitif dari berbagai tindakan. 
2. Metode Keteladanan

Metode Keteladanan (Uswah) adalah metode pendidikan yang diterapkan dengan cara memberi contoh-contoh (teladan) baik yang berupa perilaku nyata, khususnya ibadah dan akhlak. Metode Keteladanan memiliki peranan yang sangat signifikan dalam upaya mewujudkan pendidikan anak usia dini, selain diajarkan secara teoritis anak juga dapat melihat secara langsung bagaimana praktisi atau pengamalan dari pendidiknya. Pendidikan sebagai proses sepanjang hayat (life long process) dan seseorang dilahirkan hingga akhir hidupnya. Pendidikan merupakan proses yang tidak pernah akan final selama sejarah kebudayaan manusia belum memasuki tahap finalnya yang tuntas.

Selain itu, konsep yang dikajia dalam tulisan ini adalah konsep hafidz dan konsep hard and soft skill. Hafidz adalah sebuah julukan atau status bagi seseorang yang mampu menghafal Al-Quran. Sedangkan Cilik ialah seseorang yang memiliki usia yang terbilang masih sangat muda. Dalam pandangan lain cilik dapat dikategorikan berdasarkan tahap perkembangan dan umur. Balita adalah istilah umum bagi anak usia 1-3 tahun (batita) dan anak prasekolah (3-5 tahun). Adapun menurut Depkes RI, masa balita (0-5 tahun) dan masa kanak-kanak (5-11tahun). Secara umum Hafidz Cilik dapat diartikan sebagai seorang anak pada usia dini yang telah mampu menghafal Al-Quran.

Hard skill adalah pengetahuan dan kemampuan seseorang. Dalam pandangan lain hard skill menggambarkan perilaku dan keterampilan yang dapat dilihat dengan mata (eksplisit). Sedangkan Basir menyatakan Soft skill adalah sesuatu yang tak kasat mata/ imajiner/ abstrak. Teknis yang dimiliki.

\section{Pola Asuh Pada Hafidz Cilik}

Dalam keluarga anak menerima pendidikan pertama dan yang paling utama. Pendidikan yang diterima oleh anak mulai dari pendidikan agama, cara bergaul, dan hubungan interaksi dengan lingkungannya. Keluarga merupakan lingkungan sosial yang pertamabagi anak. Dengan kehadiran seorang anak dalam keluarga, komunikasi dalam keluarga menjadi lebih penting dan intensitasnya harus semakin meningkat, dalam artian keluarga ada komunikasi yang baik dan sesering mungkin antara orang tua dan anak.

Sebagaimana telah diketahui bahwa penanaman nilai-nilai yang baik akan membentuk karakter seorang anak yang menjadi landasan atau pedoman mereka dalam besikap dan berperilaku. Selain dari pada itu, karakter-karakter ini juga akhirnya membentuk kecerdasan moral. Jika sejak dini anak tidak diajarkan nilai-nilai budi pekerti Maka jika anak menginjak usia dewasa akan mengembangkan sikap destruktif atau cenderung ke arah brutal, tentu setiap orang tua tak ingin ini terjadi. Pertama, nilai yang harus diajarkan adalah nilai yang menjadi Pedoman bagi manusia, yaitu agama. Jika anak telah memiliki dasar agama yang baik, maka nilai-nilai yang lain akan dengan mudah untuk diterima dan diterapkan. Kedua, tanggung jawab, mandiri, disiplin dan jujur. Nilai ini penting agar anak nantinya bisa mandiri dan bertanggung jawab atas apa yang ia lakukan. Ketiga, menghormati dan menghargai orang lain. Keempat, etika dan sopan santun. Kelima, berbagi kasih sayang, rendah hati. Keenam, saling tolong menolong dan gotong royong.

Moral adalah aspek yang merupakan sumber energi manusia untuk bertindak sesuai dengan prinsip-prinsip moral yang ada, dan merupakan perwujudan pemahaman tentang bentuk implementasi anak dalam kehidupan sehari-hari. Tindakan-tindakan yang bertentangan dengan nilai-nilai yang ada dalam masyarakat khususnya agama sebisa mungkin melalui contoh-contoh yang tentunya ringan dipahami, seperti meninggalkan sholat, tidak berbakti kepada orang tua.

\section{Membentuk Pola Pikir (Mindset)}

Pola pikir (Mindset) adalah cara menilai dan memberikan kesimpulan terhadap sesuatu berdasarkan sudut pandang tertentu. Perbedaan pola pikir seseorang disebabkam oleh bedanya jumlah sudut pandang yang dijadikan dasar, landasan atau alasan. Bayaknya sudut pandang seseorang untuk berpikir dipengaruhi oleh emosi (mentalty), pendidikan dan pengalaman. Pola pikir anak pada usia dini merupakan suatu kondisi yang rentan dan butuh pendidikan yang baik, kecakapan orang tua pada masa itu sangat dibutuhkan. Semua orang, baik itu anak-anak dan dewasa memiliki pola pikir yang berbeda-beda, namun mindset tersebut bisa diubah dari waktu ke waktu, mengubah mindset yang ada 
pada ada anak bukanlah perkara yang mudah, akan tetapi semua itu bisa dilakukan dengan cara mempengaruhi komponen pembentuk mindset yaitu pemberian ilmu pengetahuan dan pengalaman.

\section{Internalisasi Nilai-Nilai}

Internalisasi diartikan sebagai penghayatan, pendalaman, penguasaan secara mendalam yang berlangsung melalui, bimbingan dan pengajaran. Sebagaimana telah dijelaskansebelumnya bahwa penanaman nilai-nilai kepada anak sangatlah penting diusia dini. Hal ini bisa dilakukan dengan cara membiasakankepada anak untuk memberi, berikan uang kepadanya, kemudian suruh anakuntuk memberi dan bersedekah. Contohnya ketika si anak sedang dibawa jalan-jalan oleh orang tuanya, ketika ada orang yang meminta-minta, maka ajarkan anak untuk memberi, berikan uang kepadanya, kemudian suruh anak untuk memberi uang tersebut kepada yang meminta tadi.

Tingkah laku atau perilaku adalah sekumpulan perlaku yang dimiliki oleh manusia dan dipengaruhi oleh adat, sikap, emosi, nilai, etika, dan genetika. penanaman keyakinan kepada anak bahwa segala sesuatu yang dilakukan selalu diawasi oleh Allah Subhanahu Wa Ta"eala perlu diajarkan sejak dini karena itu dapat membendung ia dikemudian hari dalam berperilaku.

Kaidah adalah patokan atau ukuran sebagai pedoman bagi manusia dalam betindak. Kaidah juga dapat dikatakan sebagai aturan yang mengatur perilaku manusia dan perilaku sebagai kehidupan bermasyarakat. Salah satunya dalam agama islam ialah perintah untuk shalatkhususnya terhadap anak. Seperti yang tertulis dalam Q.S Luqman: ayat 17.

Model pendidikan adalah upaya mendidik dan mengajarkan perilaku yang diterapkan pada anak terkait dengan tata cara mendidik dan memelihara serta membimbing keluarga, sebagai pengasuh dan pembimbing dalam keluarga yang meletakkan dasar moral, etika dan perilaku yang baik pada anaknya. Ketika anak sudah mulai bisa berbicara dan berjalan. Orang tua dapat membiasakan anak untuk menerapkan perilaku yang yang baik. Hal ini dimulai dari orang tua, jika orang tua menunjukan perilaku terhadap anak. Maka hal tersebut adalah merupakan awal dari pengenalan perilaku yang baik pada anak.

Pola asuh adalah pola perilaku yang diterapkan pada anak dan bersifat relatif konsistensi dari waktu ke waktu, dalam mengasuh anak orang tua cenderung menggunakan berbagai pola dan caracara tersendiri dalam mewujudkan keinginan orang tua. Keinginan ini kemudian akan membentuk pola asuh yang ditanamkan orang tua kepada anak-anak. Pola asuh menurut Diana Baumrind, pada prinsipnya merupakan parental control yaitu bagaimana orang tua mengontrol, membimbing, mendampingi anak-anaknya untuk melaksanakan tugas-tugas perkembangannya menuju pada proses pendewasaan.Untuk itu orang tua memerlukan aspek pendorong, meskipun tidak semua orang tua mengetahui pola asuh yang ada, terlebih kepada orang tua yang ingin menjadikan anaknya sebagai hafidz di usia dini, pola asuh yang diterapkan meliputi:

a) Interaksi antar anggota keluarga

b) Pengenalan nilai-nilai positif dan negative

c) Membentuk pola piker

d) Internalisasi nilai-nilai

e) Pembentukan tingkah laku

f) Kaidah-kaidah (Kepercayaan, Kesusilaan, Kesopanan, dan Hukum).

Konsep diatas merupakan upaya orang tua dalam mendidik, mengasuh dan membina anakanaknya, sebagaimana grand theory yang digunakan ialah teori tindakan sosial dikemukakan oleh Max Weber mempunyai relevansi terhadap usaha yang dilakukan orang tua hafidz cilik, Max Weber mengemukakan dalam tipe tindakan instrumentally rational action dan Value Rational Action, tindakan yang pada dasarnya dilakukan mengingat eksisnya kepentingan dan tujuan tertentu serta adanya tindakan semacam nilai-nilai terkait dengan agama.

Dengan kata lain, tindakan yang dilakukan oleh orang tua hafidz cilik dalam mengasuh anaknya didasarkan pada pertimbangan rasional dan nilai-nilai yang secara sadar dipilih untuk mencapai tujuannya yaitu menjadikan anak seorang penghafal Al Quran di usia belia atau dikenal dengan istilah hafidz cilik. Hasil penelitian juga menunjukkan bahwa, metode keteladanan mempunyai pengaruh yang signifkan terhadap tumbuh kembang anak. Khususnya perkembangan kemampuan Hard skll dan Soft skill nya. Metode Keteladanan (Uswah) adalah metode pendidikan 
yang diterapkan dengan cara memberi contoh-contoh (teladan) baik yang berupa perilaku nyata, khususnya ibadah dan akhlak. itu dapat kita temui bahwasanya seorang anak hafidz cilik yang telah dibekali dengan segala pembiasaan, berupa penanaman nilai-nilai dan kaidah-kaidah dari orang tuanya, serta pengenalan huruf hijayyah dan rutin mendengarkan ayat Al quran baik dari media mp3 ataupun ditartilkan langsung oleh orang tuanya.

\section{KESIMPULAN}

Kehadiran seorang anak di dalam keluarga adalah pelengkap kebahagian bagi kedua orang tuanya. Di samping Allah memberikan anugrah tersebut, Allah juga memberi amanah kepada orang tua untuk merawat, mengasuh, dan mendidik anak. Namun, orang tua sering lalai terhadap masa-masa perkembangan anak yang sangat kritis, pendidikan dini pada hafidz cilik menjadi dasar perkembangan pengetahuan mereka, yang faktor utamanya bersumber dari keluarga.

\section{DAFTAR PUSTAKA}

A.Azimul, Hidayat. (2008). Pengantar Ilmu Kesehatan Anak untuk Pendidikan Kebidanan. Jakarta: Salemba Medika

Alfiana, Ester. (2013). Pola Asuh Orang Tua Terhadap Anak dalam Keluarga pada Bidang Pendidikan.

Anwar dan Adang. 2013. Sosiologi Untuk Universitas (Cetakan Kesatu). Bandung: PT Refika Aditama.

Arikunto, S. (2006). Prosedur Penelitian Praktek. Jakarta: Rineka Cipta.

Ariesto Hadi Sutopo dan Adrianus Arief. 2010. Terampil Mengolah Data Kualitatif dengan NVIVO. Jakarta

Arini Hidayah. (1998). Televisi dan Perkembangan Sosial Anak. Yogyakarta: Pustaka Pelajar, hal. 45

Basir, S. (2011). Soft Skill VS Hard Skill. Jakarta Timur: Kantor Ankuntan Publik Syarief Basir dan Rekan.

Baurind Santrock. (1998). Perkembangan Sosial dan Proses Keluarga.

Baumrid, D. (1967). Child Care Pratices Anteceding Three Patterns of Preschool Behavior. Genetic Psychology Monographs, 75 (1). 43-88

B.R. Hergenhahn \& Matthew H. Olson. 2010. Theories of Learning (Teori Belajar), alih bahasa: Tri Wibowo B.S., III, Jakarta: Prenada Media Group. 325

Bukhari Umar. (2010). Ilmu Pendidikan Islam. Jakarta: Amzah

Departemen Kesehatan RI. (2005). Pedoman Pelaksanaan Simulasi, Deteksi dan Intervensi Dini Tumbuh Kembang Anak.

Departemen Kesehatan RI. (2009). Asuhan Kesehatan Anak dalam Konteks Keluarga

Depdikbud. (1996). Kamus Besar Bahasa Indonesia, Cet. Ke-15. Jakarta: Bulan Bintang, hal. 692

Elizabeth, B. Hurlock. (1995). Perkembangan Anak Jilid II. Jakarta: Erlangga

Zul Fajri, Ratu Aprilia Senja. (2000). Kamus Lengkap Bahasa Indonesia. Difa Publisies.

Fathul-Bari, Kitab al-janaiz III/219, hadits no. 1358, 1359, dan Shahih Muslim Syarh Nawawi, tahqiq: Khalil Maemun Syiha, XVI/423 dst, hadits no. 6697.

Goleman, Daniel. (1997). Mengapa EL lebih penting daripada IQ. Edisi 6. Sun. Jakarta.

Islami, Faizal Alam. (2012). Analisis Pengaruh Hard Skill, Soft Skill dan Motivasi Terhadap Kinerja Tenaga Penjual.

Jamal Abdurrahman. (2010). Islamic Parenting. Pendidikan Anak Metode Solo. Penerbit: AQWAM.

Map data (02019. Google

Muallifah. (2009). Pscho Smart Parenting.

Muhammad Yaumi dan Nurdin Ibrahim. (2013). Pembelajaran Berbasis Kecerdasan Jamakmengidentifikasi dan Mengembangkan Multi talenta Anak. Jakarta: Pranamedia Group

M. Ngalim Purwant, MP. (2004). Ilmu Pendidikan Teoritis dan Praktis. Bandung: PT. Remaja Rosdakarya.

M. Sitorus. (2003). Berkenalan dengan Sosiologi 1 untuk siswa SMU kelas 2. Erlangga. Jakarta, hal. 12 
Papalia, D.E. (2004). "Human Development", $\left(9^{\text {th }}\right.$ ed). Mc Graw Hill, New York. Pemerintah. (2019). Kelurahan Karampuang.

Peraturan Daerah Kota Makassar. No. 3. Tahun 2009. Tentang Pembentukan dan Susunan Organisasi Perangkat Daerah Kota Makassar.

Peraturan Pemerintah Nomor 73 Tahun 2005. Tentang Kelurahan.

Ramadhan, M. (2012). Metode Keteladanan (Uswah) Dalam Pendidikan Islam. Jakarta: Bumi Aksara

Riwayat Hadist. Hakim 1/756 dan dihasankan Al-Abani 
